\title{
Impact of conformations and size on the antileishmanial activity of new quinazoline derivatives
}

\author{
Cesar Mendoza-Martínez, ${ }^{*[a]}$ Alejandro Rodríguez-Lezama, ${ }^{[a]}$ Norma Galindo-Sevilla, ${ }^{[c]}$ Fernando \\ Cortés-Guzmán, ${ }^{[d]}$ Jessica Hernandez-Pineda, ${ }^{[c]}$, Abril Nieto-Lara, ${ }^{[b]}$ and Francisco Hernandez Luis ${ }^{*[b]}$
}

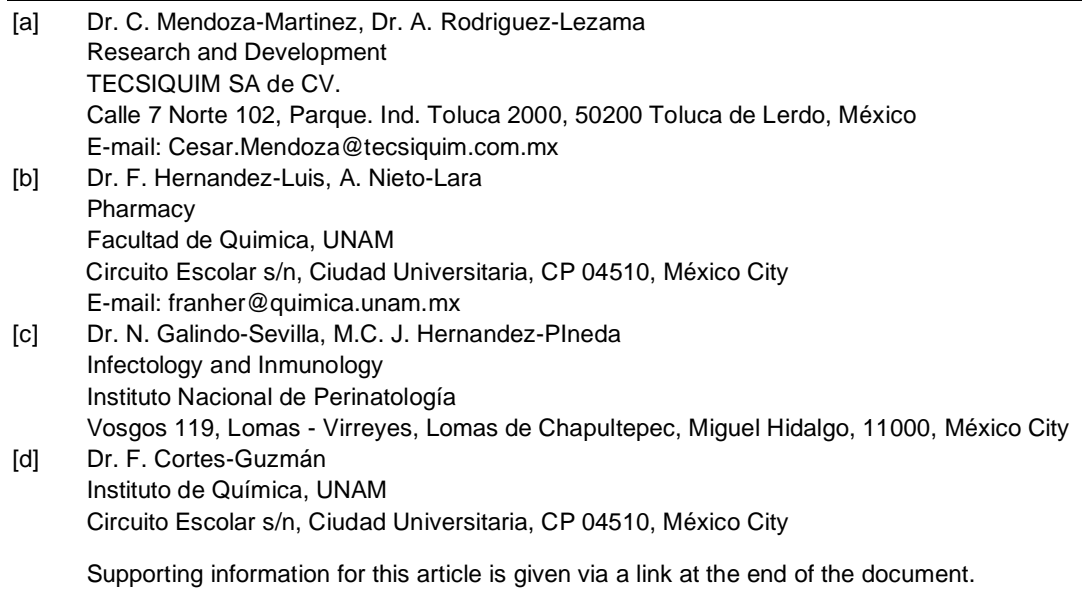

\begin{abstract}
We report here new quinazoline derivatives designed to improve the antileishmanial activity. Design-led to chemical changes based on various approaches to explore better candidates for in-vivo studies. Mainly, $N^{6}$-substitution in the quinazoline core (size and double substitution), and fluorinated methoxy and ethoxy groups link to the benzyl substituent have a profound impact on the biological activity. These chemical changes can modify physicochemical properties, particularly those regarding the conformational space. As a consequence, this affects the way these molecules bind the target, as our theoretical studies suggest. For the first time, we describe a possible non-classic hydrogen bond in difluoromethoxy, trifluoromethoxy and tetrafluoroethoxy derivatives, which opens the possibility to design new compounds considering that this unique property is prone to modify the interactions at a molecular level with the target.
\end{abstract}

\section{Introduction}

The development of new drugs has taken advantage of a significant number of molecular scaffolds, which increase the probability to find active compounds. In general, these scaffolds are present massively in molecules to treat a broad range of diseases. ${ }^{1,2}$ Nevertheless, new methodologies are being developed to fine-tune their biological activity spectra, and this is a hot topic in medicinal chemistry and drug discovery research. For our purposes, we use a combination of different techniques to explain biological systems such as $A b$-initio studies and molecular dynamics to reveal the key of the interaction between small molecules and some important targets in parasitic diseases. The primary way to modify physicochemical properties goes through the chemical modifications in the scaffold. Here is where software and new computational tools may help to understand better how to alter such structures. ${ }^{3,4}$

For instance, one of the most prevalent parasitic diseases is leishmaniasis. The clinical manifestations may range from single cutaneous lesions $(C L)$ to fatal visceral leishmaniasis (VL). This disease is endemic in 98 countries with an annual estimated incidence of 300,000 of visceral leishmaniasis (VL) cases and 1 million of cutaneous leishmaniasis $(C L)^{5,6}$.

Our group works in modifications of the attractive scaffold quinazoline, to develop new therapeutic options for leishmaniasis and other parasitic diseases. This quinazoline nucleus has shown versatility in different diseases and specificity to some targets. Our approach has given some antiparasitic agents with a broad perspective to become an alternative therapy (Figure 1)., 7,8

Previously our group reported the discovery of some molecules with antiparasitic properties against Trypanosoma cruzi. $L$. mexicana and Plasmodium berghei, and low toxicity in mammalian cells. Regarding the toxicity, compounds with high toxicity cannot go beyond the preclinic boundary and most of the drug design campaigns pursuit to develop safe compounds. Fortunately, the compounds discovered are not toxic at therapeutic levels which lead further research and development of new derivatives with enhanced properties. A plausible mechanism of action of these compounds is the inhibition of DHFR, PTR1, and most likely, the inhibition of another unknown pathway. The additional mechanism remains uncertain, but there 
is some evidence that it can be through the disruption of the mitochondrial respiratory chain.

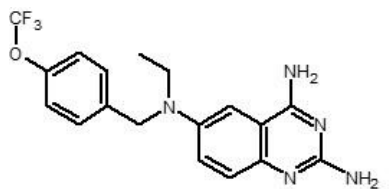

CF3_QZ

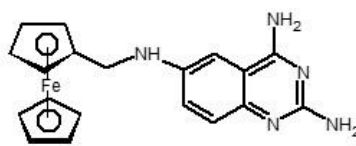

$\mathrm{H2}$
Figure 1. Leads synthesised and reported previously.

In this paper, we report antileishmanial assays and theoretical studies of some new quinazoline derivatives. These compounds, designed under a multidisciplinary approach, combine knowledge of computational chemistry, organic synthesis, and cell biology.

\section{Results and Discussion}

\section{Design}

Our research group has used three approaches in this work, to analyse what are the requirements for an excellent antileishmanial activity. Quinazoline derivatives synthesised are shown in Table 1 and 2. Some of these compounds showed good antiprotozoal activity.

The first approach is the number of fluorine atoms attached to these molecules. Compounds 1, 17 and 18 do not have fluorine atoms; others have two (2-5), three $(\mathbf{6 - 9}, \mathbf{1 4 - 1 6})$ and four $(\mathbf{1 0}$ 13). For this, there are three considerations. First, there was interest to test the effects of the number of fluorine atoms and how they can impact the physicochemical properties.

Table 1. Benzyl quinazoline derivatives synthesised<smiles>[R]c1cc([R])c(CN([R])c2ccc3nc(N)nc(N)c3c2)cc1[R]</smiles>

\begin{tabular}{|c|c|c|c|c|}
\hline Compound & $\mathrm{R}$ & $\mathrm{R}^{1}$ & $\mathrm{R}^{2}$ & $\mathrm{R}^{3}$ \\
\hline 1 & $-\mathrm{H}$ & $-\mathrm{OCH}_{3}$ & $-\mathrm{H}$ & $-\mathrm{H}$ \\
\hline 2 & $-H$ & $-\mathrm{OCF}_{2} \mathrm{H}$ & $-\mathrm{H}$ & $-H$ \\
\hline 3 & $-\mathrm{C}_{2} \mathrm{H}_{5}$ & $-\mathrm{OCF}_{2} \mathrm{H}$ & $-H$ & $-H$ \\
\hline 4 & $-H$ & $-H$ & $-H$ & $-\mathrm{OCF}_{2} \mathrm{H}$ \\
\hline 5 & $-\mathrm{C}_{2} \mathrm{H}_{5}$ & $-H$ & $-H$ & $-\mathrm{OCF}_{2} \mathrm{H}$ \\
\hline 6 & $-H$ & $-\mathrm{OCF}_{3}$ & $-H$ & $-H$ \\
\hline 7 & $-\mathrm{C}_{2} \mathrm{H}_{5}$ & $-\mathrm{OCF}_{3}$ & $-H$ & $-H$ \\
\hline 8 & $-\mathrm{H}$ & $-\mathrm{H}$ & $-\mathrm{OCF}_{3}$ & $-H$ \\
\hline 9 & $-\mathrm{C}_{2} \mathrm{H}_{5}$ & $-H$ & $-\mathrm{OCF}_{3}$ & $-H$ \\
\hline 10 & $-H$ & $-\mathrm{OCF}_{2} \mathrm{CF}_{2} \mathrm{H}$ & $-H$ & $-H$ \\
\hline 11 & $-\mathrm{C}_{2} \mathrm{H}_{5}$ & $-\mathrm{OCF}_{2} \mathrm{CF}_{2} \mathrm{H}$ & $-H$ & $-H$ \\
\hline 12 & $-H$ & $-H$ & $-\mathrm{OCF}_{2} \mathrm{CF}_{2} \mathrm{H}$ & $-\mathrm{H}$ \\
\hline 13 & $-\mathrm{C}_{2} \mathrm{H}_{5}$ & $-H$ & $-\mathrm{OCF}_{2} \mathrm{CF}_{2} \mathrm{H}$ & $-H$ \\
\hline 14 & $-H$ & $-H$ & $-\mathrm{OCF}_{3}$ & $-\mathrm{OH}$ \\
\hline 15 & $-\mathrm{C}_{2} \mathrm{H}_{5}$ & $-H$ & $-\mathrm{OCF}_{3}$ & $-\mathrm{OH}$ \\
\hline 16 & $4-\mathrm{OCF}_{3} \mathrm{PhCH}_{2}$ & $-\mathrm{OCH}_{3}$ & $-H$ & $-H$ \\
\hline
\end{tabular}

Table 2. Adamantyl quinazoline derivatives synthesised.
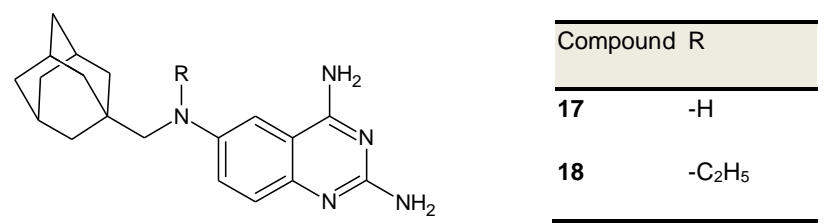

Some papers report a remarkable impact of fluorine atoms on pharmacodynamics and pharmacokinetics. ${ }^{11}$ We must also consider that methoxy and ethoxy radicals, and its variants with fluorine atoms can have new behaviours such as was previously reported. Liu et al. mentioned the possibility of conformational transitions in difluoromethoxy and trifluoromethoxy derivatives. They appointed that most of trifluromethoxybencene derivatives exist as orthogonal conformers and difluoromethoxybencene derivatives as coplanar conformers. Additionally, the position of the fluorinated methoxy or ethoxy moiety $(o, m$ and $p)$ in the benzene ring linked to the amine group at 6-position is analysed further. The patron of substitution is essential in many targets; this variation could change the interaction with the receptor and have an impact overall the biological activity. 
The second approach is the size of the substituent link to amine at 6-position. Previously, we synthesised and tested compounds varying this parameter. In this work, we compare the size of derivatives with fluorine atoms, ferrocene, and adamantane. In terms of molecular shape, adamantane is a bulky substituent. Ferrocene has a closed shape but still a bit smaller than adamantane. Ferrocene and adamantane are voluminous compared with derivatives with fluorine atoms. These substituents can also confer hydrophobicity to quinazoline derivatives. From our previous work, this appears needed for this type of antiparasitic compounds.

The third approach is regarding the global conformation due to a second substituent (ethyl) added to the amine at 6-position of the quinazoline nucleus. We conducted a theoretical study to clarify which structure has the lowest energy, and we compared this with NMR data in solution.

A summary of the three approaches described before is shown in Figure 2.

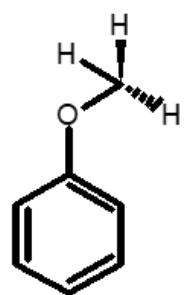<smiles>FC(F)Oc1ccccc1</smiles>

Methoxy<smiles>FC(F)(F)Oc1ccccc1</smiles><smiles>FC(F)[C@@H](F)Oc1ccccc1</smiles>

Tetrafluoroethoxy<smiles>[R]c1ccc([R])c([R])c1</smiles>

Fluoromethoxy derivatives
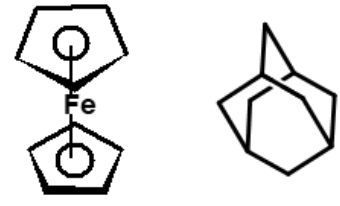

Ferrocene Adamantane

\section{Number of fluorine atoms}<smiles>[R]CNc1ccc2nc(N)nc(N)c2c1</smiles>

\section{$N^{6}$-substitution}

Figure 2. Three approaches for quinazoline derivatives designed.

\section{Ab-initio studies and validation with NMR}

Ab-initio studies were conducted to determine the most stable conformation for compounds with a different number of fluorine atoms and for investigating the effect of a double substitution in amine at 6-position. The goal was to find conformational changesbiological activity correlations. For derivatives with fluorine atoms, the tool modredundant was implemented in Gaussian, to analyse energetic profiles of representative compounds with methoxy, difluoromethoxy, trifluoromethoxy and tetrafluoroethoxy moieties. First, the analysis was performed on compounds 1, 2, 6 and 10, calculating dihedral angle $v s$ the energy difference $(\Delta \mathrm{E})$, as shown in Figure 3a. We found that there is a different conformational preference from each compound. Two major conformations detected, are at the same time, a minimum in the potential energy surface. These conformations are coplanar and orthogonal to the aromatic ring. The difluoromethoxy derivative (2) appears stabilising more a coplanar structure which mimics the methoxy derivative (1); however, there is still a possibility to find the orthogonal conformation less populated. On the other hand, trifluoromethoxy derivative (6) stabilises more the orthogonal conformation with a coplanar structure less populated. It was interesting to find that tetrafluoroethoxy derivative (10) has an equal population of coplanar and orthogonal structures, which is a consequence either the size of the substituent or the number of fluorine atoms, making it different from the other two fluorinated compounds $(2,6)$. 
a)

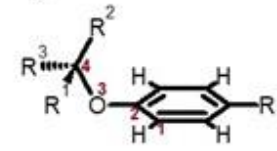

$1 R^{1}, R^{2}, R^{3}=H$

$2 R^{1}, R^{2}=F, R^{3}=H$

$6 R^{1}, R^{2}=F, R^{3}=F$

$10 R^{1}, R^{2}=F, R^{3}=C F_{2} H$

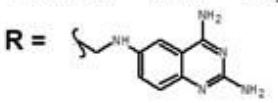

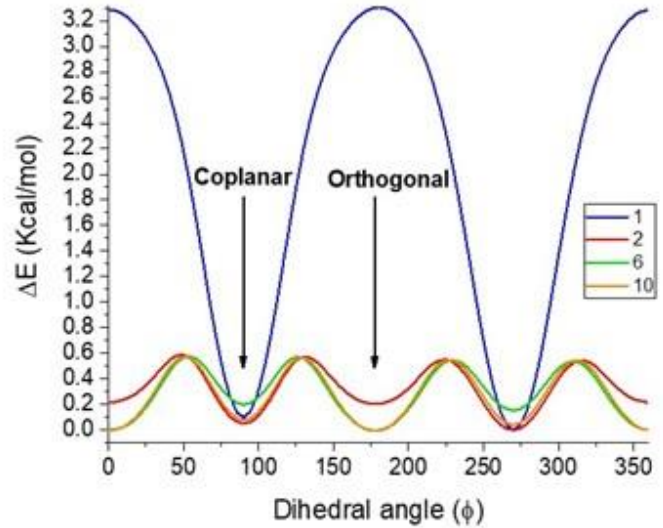

b)
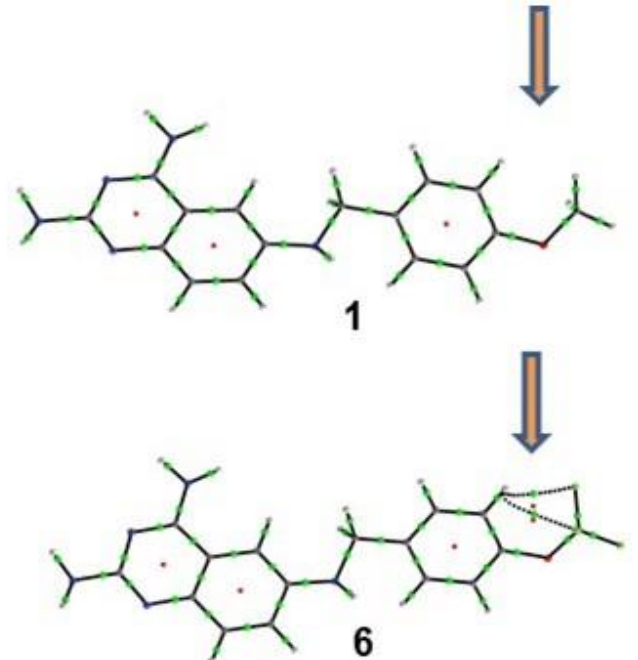

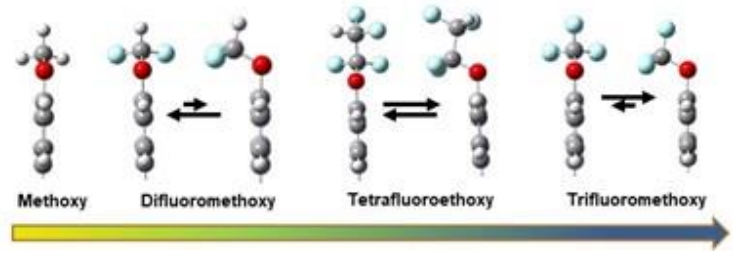

Figure 3. a) Conformational analysis around of the dihedral angle C1-C2-O3-C4 of 1, 2, 6, 10 at B3LYP 6-31G** theory, b) QTAIM analysis applied in 1 and 6, at B3LYP $6-31 \mathrm{G}^{\star *}$ theory in coplanar conformations.

The equilibrium between coplanar and orthogonal conformations was not that obvious in the crystal structures analysis previously done by Liu et. al. However, a question was pointed about if this equilibrium is highly dependent on the electronic environment in the ring or if this equilibrium is a consequence of a kind of intramolecular interaction such as a non-classical hydrogen bond between fluorine atoms and aromatic hydrogen atoms. QTAIM theory applied for compound 2, 6 and 10, shows an evident bifurcated hydrogen bond that might be the explanation of this stabilisation despite the steric repulsion (Figure 3b). In 1, coplanar conformation is the most stable and orthogonal does not even exist. This stabilisation is mediated by electron delocalisation more than a hydrogen bond where there is a poor steric repulsion. We selected some compounds from the CDCC archive with trifluoromethoxy substituents to find evidence of these phenomena. Some of these molecules have some variation between orthogonal and coplanar conformations (Figure. 4). Conformational preferences can be due to the interactions that we proposed here and not because of the crystal packing itself.

We believe this non-classic hydrogen bond might be present in difluoromethoxy and tetrafluoroethoxy derivatives as our theoretical results show. However, further studies are needed to prove this hypothesis and answer also the question if this equilibrium is dependent on the electronic environment.
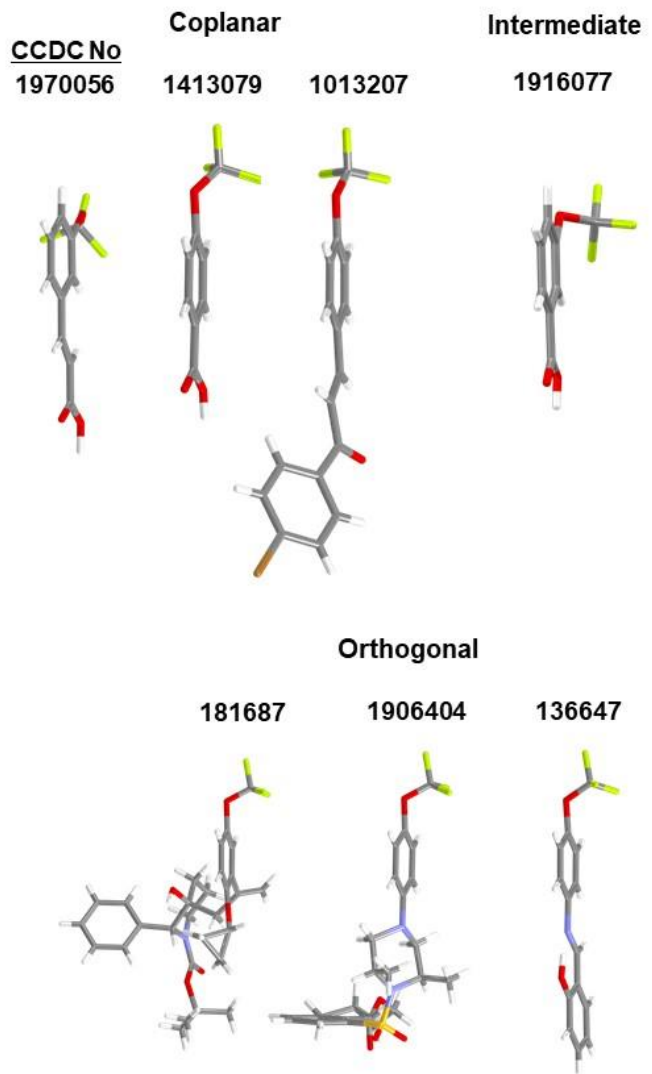

Figure 4. Compounds selected from CCDC database. 
The other aspect to consider in the set of compounds is the global conformation. We have synthesised compounds with only one substituent and their analogues with two substituents at the $N^{6}$ position. A second substituent is an ethyl group which increase the antiparasitic potency in compounds previously synthesised. 7,8 Ab-initio calculations on compounds without ethyl, shows stabilisation of a staggered conformation. These results are in good agreement with the X-ray structure determined for compound $1,{ }^{12}$, and NMR NOESY studies show the same behaviour in solution with spatial proximity between methylene group (H9) and aromatic hydrogen $6(\mathrm{H} 6)$ but not with aromatic

a) Staggered conformation
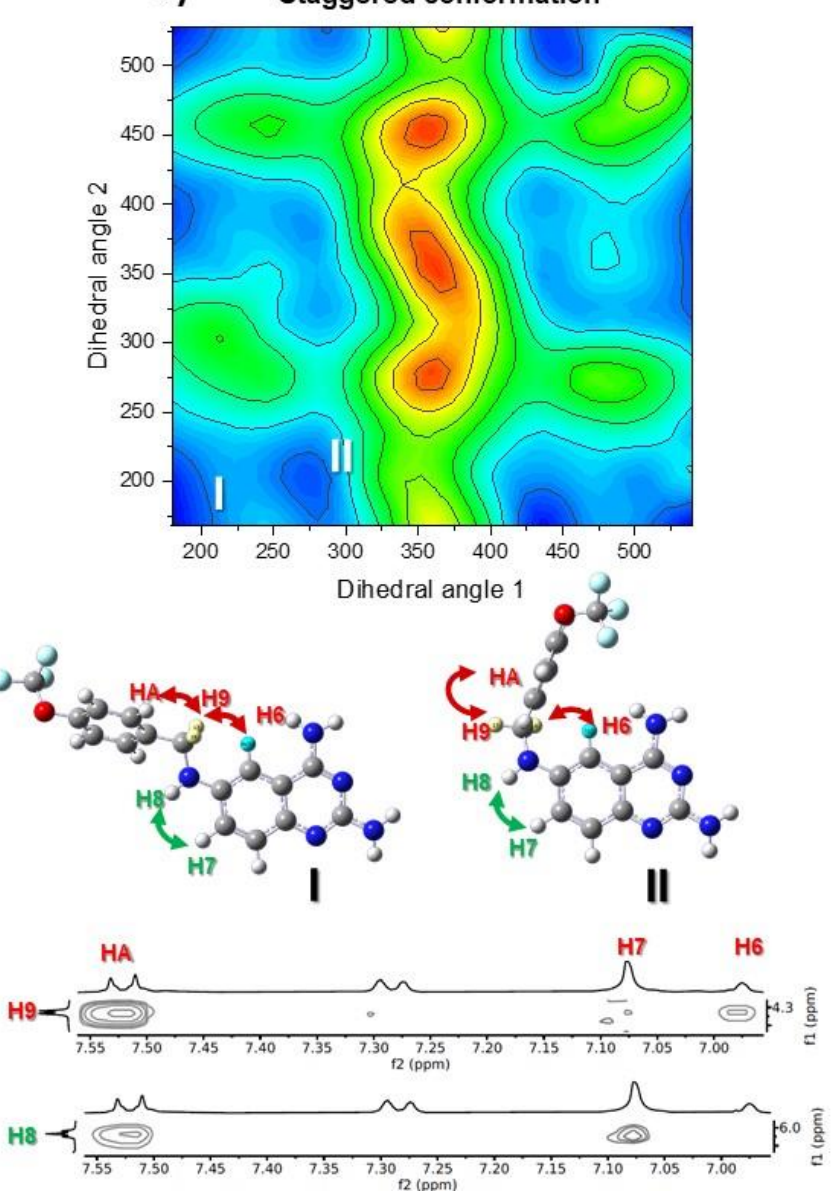

hydrogen $7(\mathrm{H} 7)$. For compounds with ethyl (as the second $N^{6}$ substituent), this connection is lost, and now there is a correlation between the methylene group and both aromatic hydrogens atoms ( $\mathrm{H6}$ and $\mathrm{H} 7)$. It means that there is an intermediate conformation either due to a more flexible rotation or a structure that allows a correlation with both hydrogen atoms spatially. From a theoretical point of view, the conformational space changes and the substitution is stabilising, especially one of the conformers shown in Figure 5b. This change has a significant impact on biological activity as we will show later in this paper.
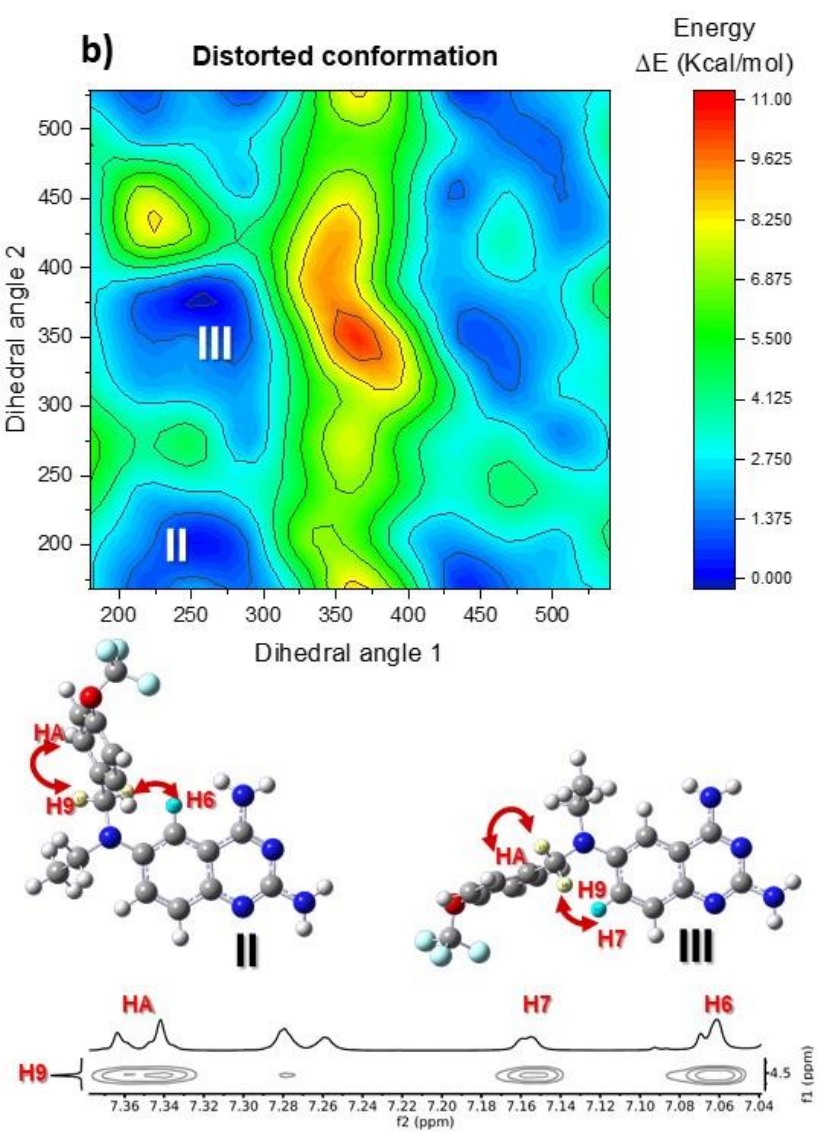

Figure 5. a) Potential energy surface (up) and NMR-NOESY studies (bottom) for 6, b) Potential energy surface (up) and NMR-NOESY studies (bottom) for $\mathbf{7}$, showing significant differences compared with compound $\mathbf{6}$.

Molecules with bulky substituents (e.g. ferrocene and adamantane) can sample other conformations that methoxy or ethoxy derivatives do not do. The reason seems to be a steric repulsion between the hydrogens atoms of the substituent and those from the methylene group linking the quinazoline nucleus. Overall the conformational space changes sampling more conformers. Results are in good agreement with what NMR in solution supports. (Figure 6).

\section{Molecular dynamics simulations on potential targets}

Previous studies, particularly, those made in our group, quinazoline derivatives can inhibit DHFR and PTR1 in parasites. With this in mind, we analysed by molecular dynamics simulations some compounds to compare the conformations on those targets. 


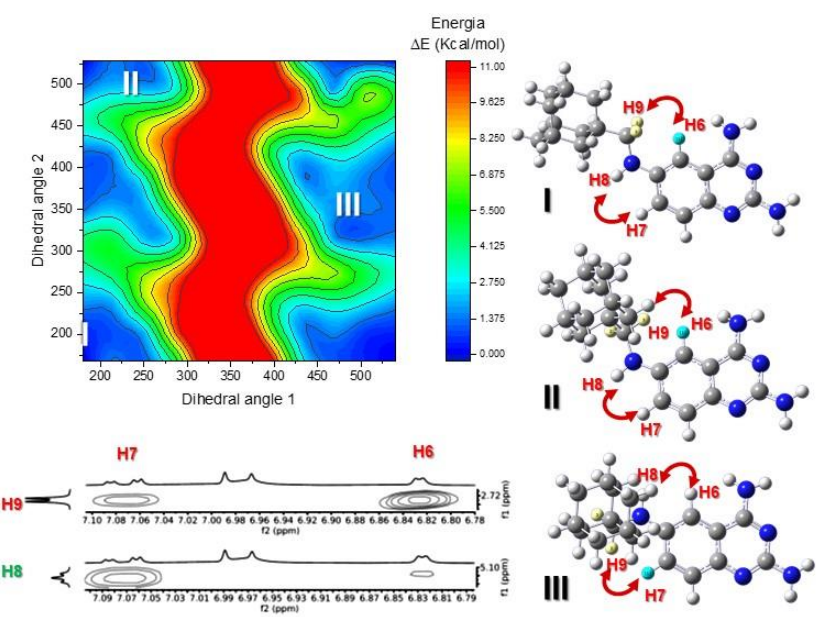

Figure 6. Potential energy surface (up) and NMR-NOESY studies (bottom) for 17. This compound is sampling more conformations than methoxy derivatives.

We were seeking to find correlations between protein-ligand complexes and the biological activity determined. We focused our study on methoxy/ethoxy moiety and the global conformation by measuring two dihedral angles, as shown in Figure 7. From these results, the coplanar conformation $\left(\sim 0^{\circ}\right)$ is more favourable in
hDHFR than in ImDHFR where the orthogonal structure stabilises more $\left(\sim 90^{\circ}\right)$. There is no clear trend on stabilisation for ImPTR1 along with the simulation. PTR1 appears to be a more flexible protein which has many fluctuations in the structure and the binding site. The difference between hDHFR and ImDHFR seems to be the volume available in the proximities of the methoxy/ethoxy moiety, which is mostly a hydrophobic pocket. That site is more prominent in ImDHFR than in hDHFR, and this allows to rotate the methoxy or ethoxy group freely. The impact on the interaction can be relevant since the fluorinated methoxy/ethoxy groups have equilibrium between coplanar and orthogonal conformations and hDHFR restricts it (Figure 8). Molecules in complexes with PTR1 show more variability of rotation.

Regarding the global conformation, there is no sign of the staggered structure, either hDHFR, ImDHFR or ImPTR1. With these results, we conclude that the staggered conformation must be prohibited when a molecule binds those proteins. It is more favourable a distorted conformation, particularly in ImDHFR (Figure 7b-II).

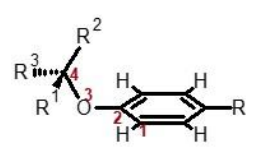

I<smiles>[R]C([R])N([R1])c1ccc2nc(N)nc(N)c2c1</smiles>

II

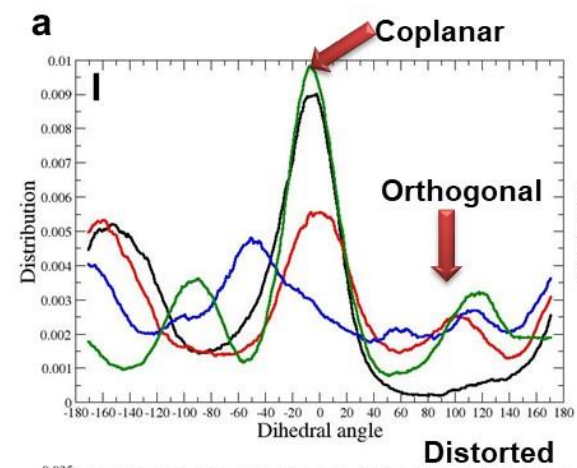

b

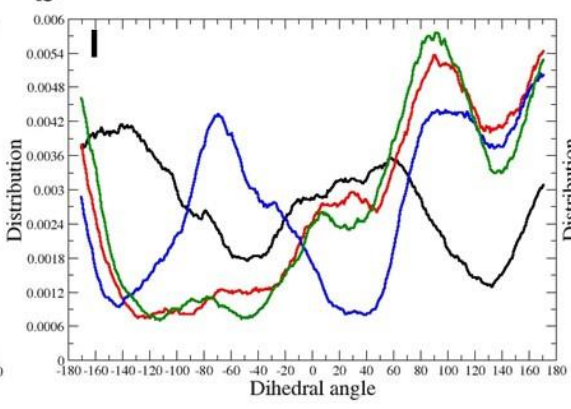

c
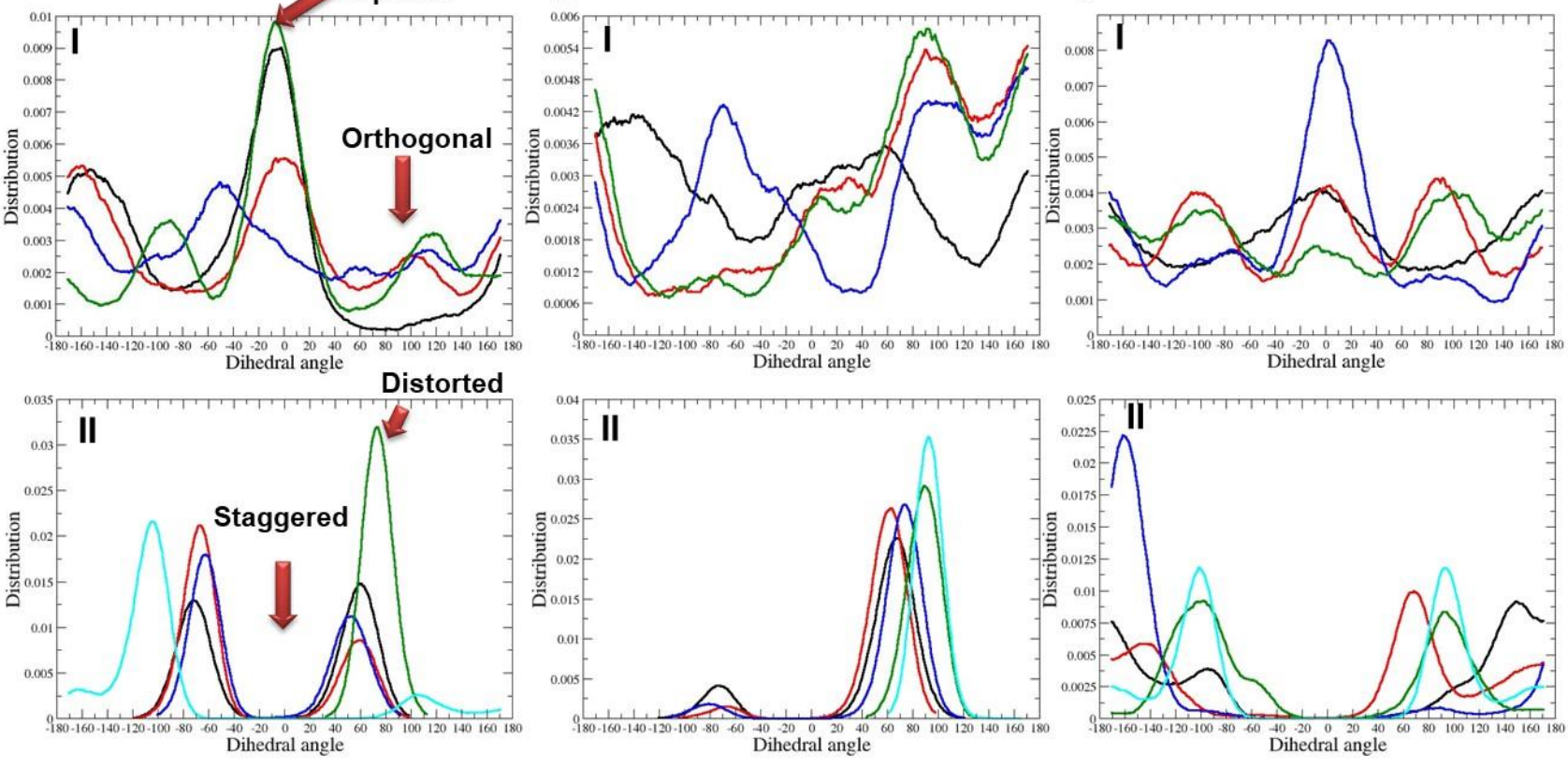

Figure 7. MD simulations performed in a) human DHFR, b) Leishmania major DHFR, c) Leishmania major PTR1, measuring two different dihedral angles (I-for methoxy/ethoxy moieties and II- for the overall conformation). Black: compound 2, red: compound 6, blue: compound 10, green: compound 7 and cyan: compound 17. 


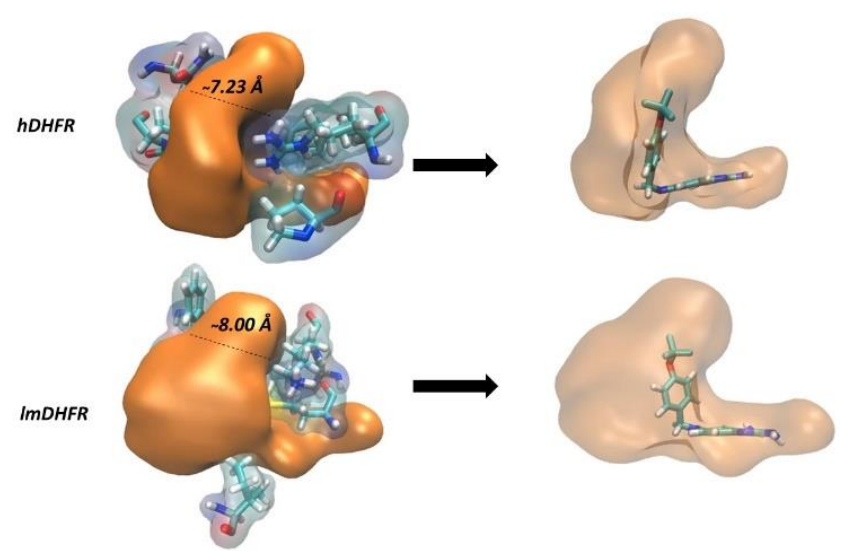

\section{Chemistry}

First, we obtained the quinazoline nucleus according to the sequence of reactions outlined in Scheme 1 . The cyclisation of 5nitroanthranilonitrile (19) with guanidine gave compound 20. A catalytic reduction of the nitro group of $\mathbf{2 0}$ brought about compound 21 (quinazolin-2,4,6-triamine). In this work, amines groups, at 2- and 4-positions, were not protected because the amine group, at 6-position, is the most reactive. The reaction between the intermediate $\mathbf{2 1}$ and some aldehydes, via reductive amination (with $\mathrm{NaBH}_{4}$ ), conducted only to desirable compounds obtained in high yields.

Figure 8. The binding pocket volume is more prominent in ImDHFR than in hDHFR, which can explain methoxy/ethoxy groups conformational preferences.<smiles>N#Cc1cc([N+](=O)[O-])ccc1N</smiles>

19
20

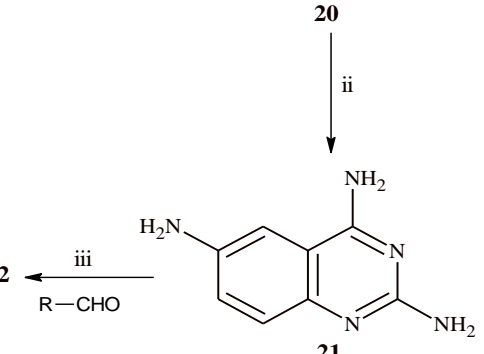<smiles>[R]CNc1ccc2nc(N)nc(N)c2c1</smiles>

$2,4,6,8,10,12,14$

$3,5,7,9,11,13,15$<smiles>[R]CNc1ccc2nc(N)nc(N)c2c1</smiles>

6, 17

16,18

Scheme 1. Reagents and conditions: (i) guanidine hydrochloride, $\mathrm{NaOH}, \mathrm{EtOH} / \mathrm{PrOH}$, reflux; (ii) $\mathrm{H}_{2}, 10 \% \mathrm{Pd} / \mathrm{C}, \mathrm{MeOH}$, r.t; (c) $\mathrm{MeOH}, 60 \stackrel{\circ}{ } \mathrm{C}, 1 \mathrm{~h}$; $0{ }^{\circ} \mathrm{C}$, $\mathrm{NaBH}_{4}$, then room temperature $1 \mathrm{~h}$, (iv) $\mathrm{CH}_{3} \mathrm{CN}, \mathrm{NaBH} 3 \mathrm{CN}$ then $\mathrm{HCl}(38 \%)$; ( v) $\mathrm{CH}_{3} \mathrm{CN} / \mathrm{CH}_{3} \mathrm{COOH}(1: 1), \mathrm{NaBH}(\mathrm{OAc})_{3}$.

The next step involved another reductive amination slightly different with $\mathrm{NaBH}_{3} \mathrm{CN}$, to place ethyl as a second substituent in amine at 6-position giving 3, 5, 7, 9, 11, 13 and 15, in good yields. For the synthesis of compound $\mathbf{1 6}$ and $\mathbf{1 8}$, we used again another reductive amination but in this case with $\mathrm{NaBH}(\mathrm{OAc})_{3}$. For compound 16 was supposed synthesised via reductive amination with $\mathrm{NaBH}_{3} \mathrm{CN}$, but, we found it difficult to afford in good yields. Amines at 2- and 4-positions also were reactive under these conditions. However, what was interesting is the possibility to obtain it in good yields by using $\mathrm{NaBH}(\mathrm{OAc})_{3}$ instead.

Only one of the aldehydes (adamantane derivative) was synthesised from the alcohol analogue by a Swern oxidation previously reported. ${ }^{12}$

\section{In-vitro antileishmanial assays}

All compounds were tested in-vitro against L. mexicana (strain MNYC/BZ/62/M379). All results were compared with previous compounds reported in our group (1, 5, 6, 16, H2). In a first analysis of the data, we noticed that compounds with fluorine have different outcomes in this test. Most active compounds were those with trifluoromethoxy group $(\mathbf{6}, \mathbf{7}, \mathbf{8}, \mathbf{9})$. The order of this activity is as follow. For compounds without double $N^{6}$-substitution is trifluoromethoxy>tetrafluroethoxy>difluromethoxy. For compounds with double $N^{6}$-substitution is trifluromethoxy>difluoromethoxy>tetrafluoroethoxy. From these results, trifluoromethoxy derivatives are the most active compounds either they have one or two substituents at $N^{6}$ position. Our theoretical results show that there is some freedom in the binding pocket of ImDHFR where the volume can hold better a trifluoromethoxy or a tetrafluoroethoxy group, maximising the contact with the hydrophobic environment. Nevertheless, because the binding pocket is too large, difluoromethoxy group, which exist mostly in a coplanar conformation, might have a difficulty to have contact with that region as it is also happening with the methoxy derivative (1). It can change when the $N^{6}$ substitution occurs having an impact in the binding mode to the target and giving more opportunity for this hydrophobic interaction. MD simulation results also suggest that trifluoromethoxy/tetrafluoroethoxy derivatives can be more 
selective for ImDHFR because the hDHFR has a smaller pocket to hold a large ligand volume.

Table 3. In vitro test for compound synthesised.

\begin{tabular}{|c|c|c|c|c|}
\hline Compound & $\begin{array}{l}\% \\
\text { survival, } 5 \\
\mu \mathrm{M} \\
\end{array}$ & $\mathrm{Cl}_{50}, \mu \mathrm{M}$ & $C \log P^{(a)}$ & TPSA \\
\hline 1 & 98 & $>10$ & 2.24 & 99.09 \\
\hline 2 & 112 & $>10$ & 2.79 & 99.09 \\
\hline 3 & 38 & 0.48 & 3.41 & 90.30 \\
\hline 4 & 100 & $>10$ & 2.75 & 99.09 \\
\hline 5 & 35 & 0.48 & 3.37 & 90.30 \\
\hline 6 & 0 & 0.055 & 3.15 & 99.09 \\
\hline 7 & 2.7 & 0.5 & 3.77 & 90.30 \\
\hline 8 & 0 & 0.062 & 3.12 & 99.09 \\
\hline 9 & 1 & 0.194 & 3.75 & 90.30 \\
\hline 10 & 65.7 & 8.95 & 3.43 & 99.09 \\
\hline 11 & 38 & 4.16 & 4.05 & 90.30 \\
\hline 12 & 82 & 8.53 & 3.41 & 99.09 \\
\hline 13 & 33 & 4.2 & 4.03 & 90.30 \\
\hline 14 & 101 & $>10$ & 3.07 & 119.32 \\
\hline 15 & 183 & $>10$ & 3.69 & 110.53 \\
\hline 16 & 0.5 & 2.65 & 3.99 & 89.86 \\
\hline 17 & 0 & 3 & 4.61 & 81.07 \\
\hline 18 & 0 & 2.3 & 4.83 & 99.54 \\
\hline $\mathrm{H} 2$ & 51 & 3 & ND & ND \\
\hline
\end{tabular}

https://www.molinspiration.com. ND: not determined.

Trifluoromethoxy derivatives also show unusual behaviour. For other compounds different of trifluoromethoxy derivatives, the double $N^{6}$ substitution has a positive effect. However, for trifluoromethoxy derivatives, this can be slightly unfavourable even though all those compounds are the best in this study. For this class of compounds, not always a double substitution improves the antileishmanial activity. This outcome suggests that there is a delicate balance between conformations of the fluorinated methoxy group and changes due to a second substituent at $N^{6}$-position. When we consider the position of the substituent in the aromatic ring, trifluoromethoxy in $m$-position, is more favourable. The volume of the substituent also seems very important here. The binding site can afford adamantane or ferrocene equally as the results show, and more importantly, the $N^{6}$-substitution does not affect this trend. Tetrafluoroethoxy is a big substituent as well; however, it might need more volume to reach the same biological activity as the compounds before mentioned. Finally, compounds $\mathbf{1 4}$ and $\mathbf{1 5}$ have no activity even though they have a trifluoromethoxy moiety in their structure. This supports that hydrophilic substituents can not contribute to a good profile. TPSA for both compounds is the highest between all the compounds reported here. $\mathrm{OH}$-methylation could bring this compound to a good profile again; however, this is a task of future work.

\section{In-vivo assays in a leishmaniasis mouse model}

Compounds $\mathbf{9}$ and $\mathbf{1 7}$ tested in an in-vivo model as a preliminary study are compounds with excellent in vitro activity, and they have good physicochemical properties predicted. Measures of the lesion induced by $L$. mexicana infection of mice treated with compound 9 show high performance. Lesion size with this compound was decreasing, and in a few cases, the lesion disappears entirely after two weeks. Compound $\mathbf{1 7}$ does not show something relevant in this model (Figure 9 and $\mathrm{SI}$ ).

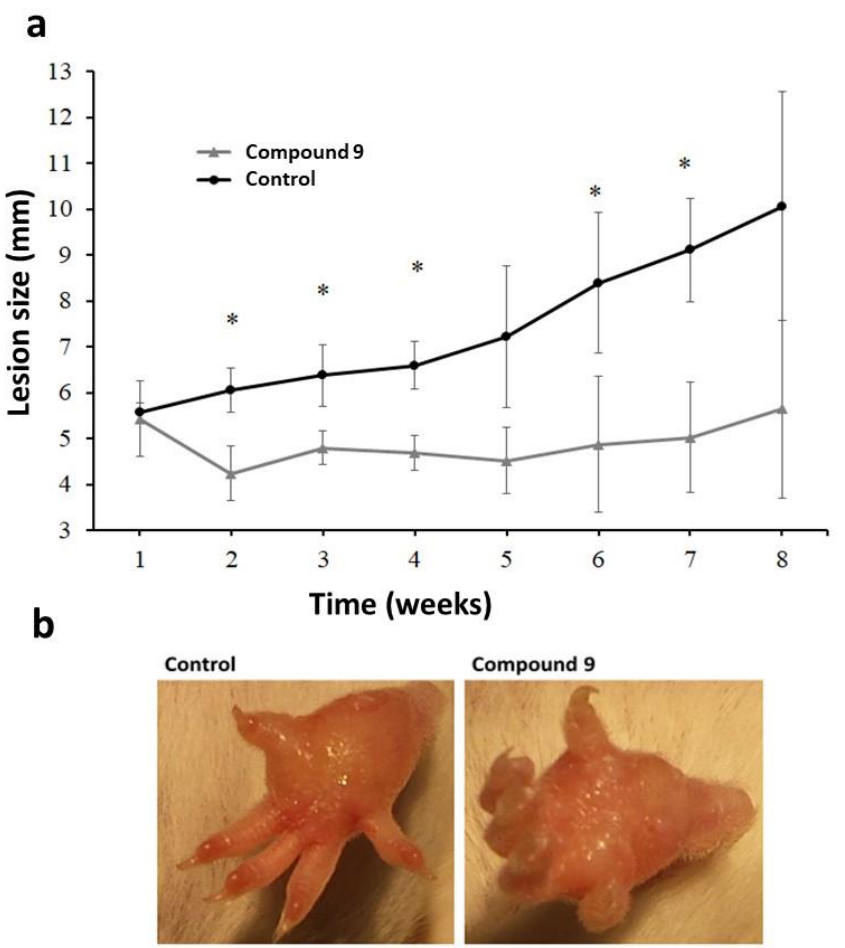

Figure 9. a) Size of the paw lesion in mice along eight weeks, b) Compound 9 reduces the size wound in an in vivo mice model of leishmaniasis.

\section{Conclusion}

Some compounds presented in this paper have a good profile invitro as antileishmanial agents. There is a qualitative correlation between computational studies and the biological activity which supports the hypothesis that they are inhibitors of DHFR and possibly PTR1. This next generation of DHFR inhibitors fluorine and adamantane based open the possibility to find better drugs against this disease. Compound $\mathbf{9}$ appears as the new leader in this study however we think we can improve this result either by 
correctly formulating it for in-vivo administration or by designing new molecules based in the knowledge gained in this work. Computational techniques could also help to address future research into the right path.

\section{Experimental Section}

\section{Materials and Methods}

Melting points were determined in open capillary tubes with a Büchi B-540 melting point apparatus and are uncorrected. Reactions were monitored by TLC on $0.2 \mathrm{~mm}$ precoated silica gel 60 F254 plates (E. Merck) with visualisation by irradiation with a UV lamp. Silica gel 60 (70-230 mesh) was used for column chromatography. IR spectra were recorded with an FT Perkin Elmer $16 \mathrm{PC}$ spectrometer on $\mathrm{KBr}$ disks. ${ }^{1} \mathrm{H}(300 \mathrm{MHz})$ and ${ }^{13} \mathrm{C}(75$ $\mathrm{MHz}$ ) NMR spectra were measured at room temperature using a Varian EM-390 spectrometer. Solvents are indicated in the text. Data for ${ }^{1} \mathrm{H}$ NMR spectra are reported as follows: chemical shifts are given in ppm relative to tetramethylsilane $\left(\mathrm{Me}_{4} \mathrm{Si}, \delta=0\right) ; J$ values are given in $\mathrm{Hz}$; splitting patterns have been designated as follows: s, singlet; $d$, doublet; q, quartet; dd, doublet of doublet; $t$, triplet; m, multiplet; bs, broad singlet. Data for ${ }^{13} \mathrm{C} N M R$ are reported in terms of chemical shift $(\delta, \mathrm{ppm})$ relative to the residual solvent peak. MS were recorded on a JEOLJMS-SX102A spectrometer by $\mathrm{FAB}[\mathrm{FAB}(+)]$ and Water SynaptG2Sspectrometer by TOF MS ES +. Catalytic hydrogenations were carried out in a Parr shaker hydrogenation apparatus. Starting materials, 5-nitroanthranilonitrile, guanidine clorhidrate were commercially available (Sigma Aldrich).

For HPLC analysis, the methanol and acetonitrile used for the mobile phase and solutions were of chromatographic grade (JT Baker, Phillipsburg, NJ, USA). Water was deionised and osmosed (17.2 M $\Omega . c m$ ) using a Milli-Q® system (Millipore, Bedford, MA, USA). The phosphates powders were analytical grade.

Synthesis of compound 21.

Compound $\mathbf{2 0}$ was synthesised as previously reported. The catalytic reduction of $20(0.5 \mathrm{~g}, 1.73 \mathrm{mmol})$ with hydrogen and $\mathrm{Pd} / \mathrm{C}(10 \%)(0.05 \mathrm{~g})$ was performed on a Parr assembly at $60 \mathrm{psi}$ at room temperature for $1 \mathrm{~h}$. The catalyst was then removed by filtration, and the filtrate was concentrated on a rotavapor under reduced pressure to yield $\mathbf{2 1}$.

\section{Synthesis of compounds 1, 2, 4, 6, 8, 10, 12, 14, H2.}

A solution of appropriate aldehyde $(1.60 \mathrm{mmol})$ and compound 21 $(1.76 \mathrm{mmol})$, in methanol $(80 \mathrm{ml})$ was stirred at $60{ }^{\circ} \mathrm{C}$ for 2 days. Then the reaction mixture was cold to $0{ }^{\circ} \mathrm{C}$ and was added $\mathrm{NaBH}_{4}$ $(0.11 \mathrm{~g}, 3.20 \mathrm{mmol})$. Later, it was stirred at room temperature for
$12 \mathrm{~h}$. After the reaction mixture was evaporated on rota vapour under reduced pressure and water cold pour above it. The solid was filtered off, washed whit cold water and dried.

Synthesis of compounds 3, 5, 7, 9, 11, 13, 15.

A solution of acetaldehyde $(0.84 \mathrm{~mL}, 14.95 \mathrm{mmol})$, compound 5 $(0.31 \mathrm{~g}, 0.89 \mathrm{mmol})$ and sodium cyanoborohydride $\left[\mathrm{NaBH}_{3} \mathrm{CN}\right]$ $(0.26 \mathrm{~g}, 4.14 \mathrm{mmol})$ were added. The mixture was subjected to constant stirring in $34 \mathrm{~mL}$ of acetonitrile for 2 minutes. Then concentrated $\mathrm{HCl}$ was added slowly until $\mathrm{pH}=2$. It was allowed to stir for half an hour, and the reaction mixture was poured into a cold solution of sodium carbonate and then filtered to obtain the product. The solid was washed with ether, filtered, and the solution obtained was concentrated to give a yellow powder. Recrystallisation from methanol gave the desired product.

\section{Synthesis of compounds 16.}

The amine 1 (1 mmol) and 4-trifluoromethoxybenzaldehyde (5 $\mathrm{mmol}$ ) were subjected to stirring at room temperature in $5 \mathrm{~mL}$ of a mixture of acetic acid and acetonitrile (1:1) with $5 \mathrm{mmol}$ of sodium triacetoxyborohydride $[\mathrm{NaBH}(\mathrm{OAc}) 3]$ for 7 days. After this time, $15 \mathrm{~mL}$ of methanol and sodium carbonate were added to neutralise the acetic acid. The solvent was evaporated, then the solid was redissolved in acetone, filtered and the obtained solution was subjected to flash chromatography for purification eluted with chloroform: methanol 98:2.

\section{Synthesis of compounds 18.}

The amine 17 (1 mmol) and Acetaldehyde $(5 \mathrm{mmol})$ were subjected to stirring at room temperature in $5 \mathrm{~mL}$ of a mixture of acetic acid and acetonitrile (1:1) with $5 \mathrm{mmol}$ of sodium triacetoxyborohydride $[\mathrm{NaBH}(\mathrm{OAc}) 3]$ for 7 days. After this time, $15 \mathrm{~mL}$ of methanol and sodium carbonate was added to neutralise the acetic acid. The solvent was evaporated, then the solid was redissolved in acetone, filtered and the obtained solution was subjected to flash chromatography for purification eluted with chloroform: methanol 98:2.

$N^{6}$-[4-(methoxy)benzyl]quinazoline-2,4,6-triamine (1)

Data reported previously.

$N^{6}$-[4-(difluoromethoxy)benzyl]quinazoline-2,4,6-triamine (2)

${ }^{1} H$ NMR (400 MHz, DMSO-d6) $\delta 7.46(d, J=8.6 \mathrm{~Hz}, 2 H), 7.15(t$, $J=74.3 \mathrm{~Hz}, 1 H), 7.12(d, J=8.5 \mathrm{~Hz}, 2 \mathrm{H}), 7.03(\mathrm{~s}, 2 \mathrm{H}), 6.94(\mathrm{~s}$, $3 H), 5.95(t, J=6.2 \mathrm{~Hz}, 1 H), 5.46(s, 2 H), 4.28(d, J=6.2 \mathrm{~Hz}, 2 H)$, ${ }^{13} \mathrm{C} \mathrm{NMR}(101 \mathrm{MHz}, \mathrm{DMSO}-d 6) \delta 161.54,158.43,149.76(t, J=$ $3.1 \mathrm{~Hz}), 145.15,142.75,137.33,129.33,125.19,123.51,118.75$, $116.50(t, J=257.4 \mathrm{~Hz}), 110.84,100.67,46.30$. MS FAB(+) M/Z $=332$, HPLC purity $=98 \%$, HPLC RT $=6.437$. 
$N^{6}$-[4-(difluoromethoxy)benzyl]- $N^{6}$-ethylquinazoline-2,4,6triamine (3)

${ }^{1} H$ NMR (400 MHz, DMSO-d6) $\delta 7.53(s, 2 H), 7.28(d, J=8.6 \mathrm{~Hz}$, $2 H), 7.21(m, 1 H), 7.15(t, J=74.3 H z, 1 H), 7.13(m, 2 H), 7.10(d$, $J=8.6 \mathrm{~Hz}, 2 \mathrm{H}), 6.18(\mathrm{~s}, 2 \mathrm{H}), 4.51(\mathrm{~s}, 2 \mathrm{H}), 3.42(q, J=6.7 \mathrm{~Hz}, 2 \mathrm{H})$, $1.08(t, J=6.9 \mathrm{~Hz}, 3 H) .{ }^{13} \mathrm{C} \mathrm{NMR}(101 \mathrm{MHz}, \mathrm{DMSO}-d 6) \delta 162.15$, 157.27, 149.82, 143.55, 140.52, 136.51, 128.79, 123.07, 122.27, $119.01,116.54(t, J=257.5 \mathrm{~Hz}), 110.83,104.27,52.58,45.04$, 12.04. MS FAB(+) M/Z = 360, HPLC purity $=95 \%$, HPLC RT $=6.865$.

$N^{6}$-[2-(difluoromethoxy)benzyl]quinazoline-2,4,6-triamine (4).

${ }^{1} \mathrm{H}$ NMR (400 MHz, DMSO-d6) $\delta 7.37$ (d, J = 7.5 Hz, 1H), 7.31 $7.25(m, 10 H), 7.23(s, 4 H), 7.21-7.11(m, 21 H), 7.08(s, 2 H)$, $7.04(t, J=74.1 \mathrm{H}, 1 \mathrm{H}), 6.92(\mathrm{~s}, 1 \mathrm{H}), 5.80(t, J=6.1 \mathrm{~Hz}, 1 \mathrm{H}), 5.61$ (s, 2H), 4.29 (d, J = 6.1 Hz, 5H). ${ }^{13} \mathrm{C} \mathrm{NMR}(101 \mathrm{MHz}, \mathrm{DMSO}-d 6)$ $\delta 162.53,158.08,149.88(t, J=2.7 \mathrm{~Hz}), 144.33,143.28,131.18$, $130.27,129.48,126.24,124.85,124.37,119.30,117.40(t, J=$ 258.1 Hz), 111.39, 101.84, 42.63. MS FAB(+) M/Z = 332, HPLC purity $=95 \%$, HPLC RT $=6.407$.

$N^{6}$-[2-(difluoromethoxy)benzyl]- $N^{6}$-ethylquinazoline-2,4,6triamine (5).

${ }^{1} \mathrm{H}$ NMR (400 MHz, DMSO-d6) $\delta 7.30$ (ddd, $\mathrm{J}=8.4,6.4,2.5 \mathrm{~Hz}$, $3 H), 7.23(t, J=74.4 \mathrm{~Hz}, 1 H), 7.22-7.15(m, 4 H), 7.13(d d, J=$ 8.8, $1.2 \mathrm{~Hz}, 1 \mathrm{H}), 7.09(t, J=8.6 \mathrm{~Hz}, 2 \mathrm{H}), 7.03(d d, J=9.4,2.6 \mathrm{~Hz}$, $3 H), 5.64(s, 2 H), 4.52(s, 2 H), 3.42(d, J=7.1 \mathrm{~Hz}, 2 H), 1.09(t, J$ $=6.9 \mathrm{~Hz}, 3 \mathrm{H}) \cdot{ }^{13} \mathrm{C} \mathrm{NMR}(101 \mathrm{MHz}, \mathrm{DMSO}-\mathrm{d} 6) \delta \mathrm{1} 161.83,158.32$, $149.19,143.73,142.80,130.14,128.60,128.30,125.31,124.75$, $121.60,118.51,116.81(t, J=257.7 \mathrm{~Hz}), 111.02,103.80,48.29$, 44.92, 12.01. MS FAB(+) M/Z = 350, HPLC purity $=99 \%$, HPLC $\mathrm{RT}=6.407$.

$N^{6}$-[4-(trifluoromethoxy)benzyl]quinazoline-2,4,6-triamine (6).

Data previously reported.

$N^{6}$-[4-(trifluoromethoxy)benzyl]- $N^{6}$-ethylquinazoline-2,4,6triamine (7).

Data previously reported.

$N^{6}$-[3-(trifluoromethoxy)benzyl]quinazoline-2,4,6-triamine (8). ${ }^{1} \mathrm{H} N M R(400 \mathrm{MHz}, \mathrm{DMSO}-d 6) \delta 7.46-7.42(\mathrm{~m}, 2 \mathrm{H}), 7.40-7.37$ (m, 1H), 7.19 (dt, J = 3.2, $1.1 \mathrm{~Hz}, 1 \mathrm{H}), 7.04(d, J=1.4 \mathrm{~Hz}, 2 \mathrm{H})$, $6.99-6.92(\mathrm{~m}, 3 H), 6.08(t, J=6.4 \mathrm{~Hz}, 1 \mathrm{H}), 5.47(\mathrm{~s}, 2 \mathrm{H}), 4.35(\mathrm{~d}$, $J=6.4 \mathrm{~Hz}, 2 \mathrm{H}) .{ }^{13} \mathrm{C} \mathrm{NMR}(101 \mathrm{MHz}, \mathrm{DMSO}-d 6) \delta 161.57,158.47$, $148.59(d, J=1.6 \mathrm{~Hz}), 145.15,143.53,142.57,130.20,126.75$, 125.24, 123.46, 120.23 ( $q, J=257.3 \mathrm{~Hz}$ ), 120.04, 119.17, 110.83, 100.81, 46.30. MS FAB(+) M/Z = 360, HPLC purity $=96 \%$, HPLC $\mathrm{RT}=6.713$.

$N^{6}$-[3-(trifluoromethoxy)benzyl]- $N^{6}$-ethylquinazoline-2,4,6triamine (9).
${ }^{1} H$ NMR (400 MHz, DMSO-d6) $\delta 7.42(t, J=7.8 \mathrm{~Hz}, 1 H), 7.28(d$, $J=5.3 \mathrm{~Hz}, 1 \mathrm{H}), 7.18(\mathrm{~d}, \mathrm{~J}=8.2 \mathrm{~Hz}, 3 \mathrm{H}), 7.11-6.98(\mathrm{~m}, 4 \mathrm{H}), 5.53$ (s, 2H), $4.54(s, 2 H), 3.41(q, J=6.9 \mathrm{~Hz}, 1 \mathrm{H}), 1.07(t, J=6.9 \mathrm{~Hz}$, 3H).. ${ }^{13} \mathrm{C} \mathrm{NMR}(101 \mathrm{MHz}, \mathrm{DMSO}-d 6) \delta 162.04,159.18,148.96$, $145.53,143.34,142.66,130.66,126.52,125.63,123.14$ (q, $J=$ $257.45 \mathrm{~Hz}), 122.41,119.82,119.46,111.28,104.80,53.89,45.55$, 13.19. $\mathrm{MS} F A B(+) \mathrm{M} / \mathrm{Z}=378$, HPLC purity $=97 \%$, HPLC RT $=7.174$.

$N^{6}$-[4-(tetrafluoroethoxy)benzyl]quinazoline-2,4,6-triamine (10). ${ }^{1} \mathrm{HNMR}(400 \mathrm{MHz}, \mathrm{DMSO}-d 6) \delta 7.50(d, J=8.6 \mathrm{~Hz}, 2 \mathrm{H}), 7.23(d$, $J=8.4 \mathrm{~Hz}, 2 \mathrm{H}), 7.05(\mathrm{~m}, 4 \mathrm{H}), 6.97(d, J=1.7 \mathrm{~Hz}, 1 \mathrm{H}), 6.76(t t, J$ $=51.9,3.0 \mathrm{~Hz}, 1 \mathrm{H}), 6.03(t, J=6.2 \mathrm{~Hz}, 1 \mathrm{H}), 5.57(\mathrm{~s}, 2 \mathrm{H}), 4.31$ (d, $J=6.1 \mathrm{~Hz}, 2 \mathrm{H}) .13 \mathrm{C} N M R(101 \mathrm{MHz}, \mathrm{DMSO}-\mathrm{d} 6) \delta$ 161.59, 158.14, 146.86, 144.38, 142.90, 139.18, 129.31, 124.81, 123.48, 121.51, $116.49(t, J=273.1 \mathrm{~Hz}), 110.79,107.93(t t, J=249.9 \mathrm{~Hz}, J=40.8$ $\mathrm{Hz}), 100.59,46.26$. MS FAB(+) M/Z = 382, HPLC purity $=99 \%$, HPLC RT $=6.734$.

$N^{6}$-[4-(tetrafluoroethoxy)benzyl]- $N^{6}$-ethylquinazoline-2,4,6triamine (11).

${ }^{1} H$ NMR (400 MHz, DMSO-d6) $\delta 7.24(d, J=8.6 \mathrm{~Hz}, 2 H), 7.22$ (s, $2 H), 7.12(d, J=8.6 \mathrm{~Hz}, 2 H), 7.11(\mathrm{~s}, 1 \mathrm{H}), 7.02(d, J=1.5 \mathrm{~Hz}, 1 \mathrm{H})$, $7.02(s, 1 H), 6.65(t t, J=51.9,3.0 \mathrm{~Hz}, 1 H), 5.76(s, 2 H), 4.44(s$, $2 H), 3.42(q, J=7.0 \mathrm{~Hz}, 2 H), 0.99(t, J=6.9 \mathrm{~Hz}, 3 H) .{ }^{13} \mathrm{C} \mathrm{NMR}$ (101 MHz, DMSO-d6) $\delta 162.21,158.19,147.15,143.32,138.83$, 129.03, 128.88, 124.38, 122.32, 121.96, $116.79(t, J=273.10 \mathrm{HZ})$, 111.20, 108.25 (tt, $J=249.9 \mathrm{~Hz}, J=40.8 \mathrm{~Hz}), 104.48,52.90$, 45.29, 12.29. MS FAB(+) M/Z $=410$, HPLC purity $=96 \%$, HPLC $\mathrm{RT}=7.159$.

$N^{6}$-[3-(tetrafluoroethoxy)benzyl]quinazoline-2,4,6-triamine (12). ${ }^{1} H$ NMR (400 MHz, DMSO-d6) $\delta 7.45-7.38(\mathrm{~m}, 2 \mathrm{H}), 7.31$ (d, $\mathrm{J}=$ $2.4 \mathrm{~Hz}, 1 \mathrm{H}), 7.12(d t, J=6.3,2.8 \mathrm{~Hz}, 1 \mathrm{H}), 7.04(d, J=1.5 \mathrm{~Hz}, 2 H)$, $7.00-6.91(\mathrm{~m}, 3 H), 6.75(t t, J=51.9,3.1 \mathrm{~Hz}, 1 \mathrm{H}), 6.07(t, J=6.5$ $\mathrm{Hz}, 1 \mathrm{H}), 5.47(\mathrm{~s}, 2 \mathrm{H}), 4.35(\mathrm{~d}, \mathrm{~J}=6.3 \mathrm{~Hz}, 2 \mathrm{H}) .{ }^{13} \mathrm{C} \mathrm{NMR}(101 \mathrm{MHz}$, DMSO-d6) $\delta 161.55,158.46,148.28,145.17,143.26,142.60$, $129.95,126.17,125.23,123.41,120.57,119.75,116.51(t, J=$ 273.10) , 110.83, 107.94 (tt, $J=250.1 \mathrm{~Hz}, J=40.6 \mathrm{~Hz}$ ), 100.74, 46.32. $\mathrm{MS} F A B(+) \mathrm{M} / \mathrm{Z}=382$, HPLC purity $=96.13 \%$, HPLC RT $=6.698$.

$N^{6}$-[3-(tetrafluoroethoxy)benzyl]- $N^{6}$-ethylquinazoline-2,4,6triamine (13).

${ }^{1} H$ NMR (400 MHz, DMSO-d6) $\delta 7.39(t, J=7.8 \mathrm{~Hz}, 1 H), 7.25$ (d, $J=7.8 \mathrm{~Hz}, 1 \mathrm{H}), 7.17(\mathrm{~s}, 1 \mathrm{H}), 7.15-6.96(\mathrm{~m}, 6 \mathrm{H}), 6.74(t t, J=$ 51.9, 3.1 Hz, 2H), $5.54(s, 2 H), 4.54(s, 2 H), 3.41$ (q, J = 6.9 Hz, 2H), $1.07(t, J=6.9 \mathrm{~Hz}, 3 H) .{ }^{13} \mathrm{C} \mathrm{NMR}(101 \mathrm{MHz}, \mathrm{DMSO}-d 6) \delta$ 162.04, 159.13, 148.68, 145.40, 143.07, 142.71, 130.45, 125.97, $125.58,122.31,120.40,120.05,115.77,111.30,105.81,104.66$, 
53.32, 45.47, 12.39. MS FAB(+) M/Z =410, HPLC purity $=94.2 \%$, HPLC RT $=7.096$.

$N^{6}$-[2-hidroxy,4-(trifluoromethoxy)benzyl]quinazoline-2,4,6-

triamine (14).

${ }^{1} H$ NMR (400 MHz, DMSO-d6) $\delta 7.21(d, J=2.5 \mathrm{~Hz}, 1 H), 7.07$ (dd, $J=9.0,2.1 \mathrm{~Hz}, 1 \mathrm{H}), 7.06-6.98(\mathrm{~m}, 3 \mathrm{H}), 6.97(d, J=1.6 \mathrm{~Hz}$, $1 H), 6.88(d, J=8.7 \mathrm{~Hz}, 1 H), 5.74(s, 1 H), 5.54(s, 2 H), 4.24$ (s, 2H). ${ }^{13} \mathrm{C} \mathrm{NMR} \mathrm{(101} \mathrm{MHz,} \mathrm{DMSO-d6)} \delta 161.59,158.18,154.32$, 144.53, 142.98, 140.57, 127.90, 124.83, 123.33, 121.40, 120.34, 120.30 ( $q, J=255.83 \mathrm{~Hz}$ ), 115.59, 110.82, 100.82, 42.00. MS $\mathrm{FAB}(+) \mathrm{M} / \mathrm{Z}=366, \mathrm{HPLC}$ purity $=99 \%$, HPLC RT $=6.541$.

$N^{6}$-[2-hidroxy 4-(trifluoromethoxy)benzyl]- $N^{6}$-ethylquinazoline2,4,6-triamine (15).

${ }^{1} H$ NMR (300 MHz DMSO-d6) $\delta 7.35-7.31(m, 1 H), 7.25(d, J=$ $2.7 \mathrm{~Hz}, 1 \mathrm{H}), 7.14(d, J=9.1 \mathrm{~Hz}, 1 \mathrm{H}), 7.06(\mathrm{~m}, 2 \mathrm{H}), 6.93(d, J=$ $8.7 \mathrm{~Hz}, 1 \mathrm{H}), 6.89(d, J=3.2,1 H), 5.85(\mathrm{~s}, 2 \mathrm{H}), 4.47(\mathrm{~s}, 2 \mathrm{H}), 3.47$ (q, $J=6.9 \mathrm{~Hz}, 2 H), 1.13(t, J=6.9 \mathrm{~Hz}, 3 H) .13 \mathrm{C} \mathrm{NMR}(75 \mathrm{MHz}$, DMSO-d6) $\delta 162.25,158.47,154.68,143.16,140.99,127.45$, 124.72, 122.34, 121.91, 127.78, 120.71, 118.95, 116.16, 111.34, 104.20, 49.11, 45.49, 12.39. MS FAB(+) M/Z =394, HPLC purity $=95.4 \%$, HPLC RT $=7.017$.

$N^{6}$-[4-(methoxy)benzyl]- $N^{6}$-[4-

(trifluoromethoxy)benzyl]quinazoline-2,4,6-triamine (16).

Data previously reported.

$N^{6}$-[1-(Adamantyl)methyl]quinazoline-2,4,6-triamine (17).

${ }^{1} \mathrm{H} N M R$ (400 MHz, DMSO-d6) $\delta 7.09$ (dd, $\left.J=9.0,2.5 \mathrm{~Hz}, 1 \mathrm{H}\right)$, $7.04-6.91(\mathrm{~m}, 3 H), 6.84(\mathrm{~d}, J=2.5 \mathrm{~Hz}, 1 \mathrm{H}), 5.45(\mathrm{~s}, 2 \mathrm{H}), 5.16(t$, $J=6.0 \mathrm{~Hz}, 1 \mathrm{H}), 2.76(d, J=5.8 \mathrm{~Hz}, 2 H), 1.94(\mathrm{~m}, 3 H), 1.65(d, J$ $=11.9 \mathrm{~Hz}, 6 \mathrm{H}), 1.57(d d, J=11.8,2.4 \mathrm{~Hz}, 6 \mathrm{H}) .13 \mathrm{C} \mathrm{NMR}(101$ $\mathrm{MHz}, \mathrm{DMSO}-d 6) \delta 161.56,158.02,144.38,144.18,124.71$, 123.69, 110.88, 99.37, 55.76, 40.19, 36.82, 27.99. MS FAB(+) $\mathrm{M} / \mathrm{Z}=338, \mathrm{HPLC}$ purity $=99 \%$, HPLC RT $=7.554$.

$N^{6}$-[1-(Adamantyl)methyl]- $N^{6}$-ethylquinazoline-2,4,6-triamine (18). ${ }^{1} \mathrm{H} \mathrm{NMR}$ (300 MHz,dmso) $\delta 7.75(\mathrm{~s}, 2 \mathrm{H}), 7.28$ (dd, $J=9,3.2 \mathrm{~Hz}$, $1 H), 7.19(\mathrm{~m}, 2 H), 6.83(\mathrm{~s}, 2 H), 3.44(q, J=6.8 \mathrm{~Hz}, 1 \mathrm{H}), 3.02(\mathrm{~s}$, 2H), $1.92(\mathrm{~s}, 3 \mathrm{H}), 1.62(\mathrm{~m}, 12 \mathrm{H}), 0.99(t, J=6.7 \mathrm{~Hz}, 3 \mathrm{H}) .{ }^{13} \mathrm{C} \mathrm{NMR}$ (75 MHz, dmso) $\delta 162.49,157.02,152.99,144.83,122.70$, 121.82, 110.81, 104.28, 46.90, 45.78, 40.90, 37.10, 28.29, 10.89. MS FAB(+) M/Z =365, HPLC purity $=97 \%$, HPLC RT $=8.435$. $N^{6}$-[1-(Ferrocenyl)methyl]quinazoline-2,4,6-triamine (19). Previously reported.

\section{Liquid chromatography}

The relative percent purity for all compounds was determined by chromatographic analysis. Standard solutions. All of them were dissolved in methanol $(10 \mu \mathrm{g} / \mathrm{mL})$. The HPLC system consisted of a Waters Alliance e2695 separation module autosampler and a 2475 Multi $\lambda$ Fluorescence detector coupled with Empower ${ }^{\mathrm{TM}}$ software (Waters, Milford, MA, USA). Gradient elution was performed on an Acentis $\AA$ RP-Amide column (150 mm $4.6 \mathrm{~mm}$ ID, particle size $5 \mathrm{~mm}$ ) (Supelco, Sigma e Aldrich, U.S.A). The column temperature was held at $35{ }^{\circ} \mathrm{C}$, and the autosampler was $4^{\circ} \mathrm{C}$. The mobile phase consisted of $10 \mathrm{mM}$ phosphates buffer at $\mathrm{pH} 3$ (\% solvent A) and acetonitrile (\% solvent $\mathrm{B})$. The gradient is shown in Table 3. The assay run time was $12 \mathrm{~min}$, with a flow rate of $1.00 \mathrm{~mL} / \mathrm{min}$. The volume of injection was $10 \mu \mathrm{L}$ into the HPLC system. Absorbance was measured at $\lambda_{\mathrm{ex}} 240$ and $\lambda_{\mathrm{em}} 500 \mathrm{~nm}$.

\begin{tabular}{lllll}
\multicolumn{5}{l}{ Table 4. Gradients for HPLC analysis } \\
\hline Time $(\mathrm{min})$ & $\mathrm{A}^{\mathrm{a}}(\%)$ & $\mathrm{B}^{\mathrm{a}}(\%)$ & Flow $(\mathrm{mL} / \mathrm{min})$ & Curve $^{\mathrm{b}}$ \\
\hline & 99 & 1 & 1.00 & 6 \\
1.00 & 99 & 1 & 1.00 & 6 \\
8.00 & 1 & 99 & 1.00 & 6 \\
9.00 & 1 & 99 & 1.00 & 6 \\
10.00 & 99 & 1 & 1.00 & 1 \\
11.00 & 99 & 1 & 1.00 & 6
\end{tabular}

a $\mathrm{A}=10 \mathrm{mM}$ phosphates buffer, $\mathrm{pH} 3.3, \mathrm{~B}=$ acetonitrile. ${ }^{\mathrm{b}}$ The curve profile 6 used for the gradient elution is a linear gradient. Curve profile 1 is an immediate change to the specified condition.

\section{In-vitro and in-vivo Antileishmanial assays}

\section{In-vitro}

Parasites from an in vitro culture of strain MNYC/BZ/62/M379 Leishmania mexicana, were cultured as promastigotes in log phase, then a 48-h culture growing in Dulbecco's modified medium with $10 \%$ FCS. The experiment was done by triplicate in 96 wells plate. Morphologic characteristic of parasites was recorded for each compound. Compounds were tested at the final concentration of 69.6 and 13.92 microMolar over 106 parasites $/ \mathrm{mL}$.

$50 \%$ inhibitory growth concentration: $I_{50}$ was measured counting alive parasites in newbauer chamber at $72 \mathrm{~h}$. Alamar blue micromethod was intended but requires many more parasites for reading ODs, 107 parasites $/ \mathrm{mL}$. In that conditions the effect of the dose differ, high doses are needed to kill parasites.

\section{In-vivo}

Intramuscular administration: Compounds were prepared at a dose of $1 \mathrm{mg} / \mathrm{mL}$ (first, $1 \mathrm{mg}$ is dissolved in $200 \mu \mathrm{L}$ DMSO hybrimax, SIGMA, St. Louis, MO, USA and then diluted with $0.8 \mathrm{~mL}$ pure injectable water from Laboratorios PISA, Guadalajara, Jal, 
Mex). $100 \mu \mathrm{l}$ was injected daily, once a day to infected mice for 28 days.

Animals. Groups of five male BALB/c mice, three weeks old, weighing $18-22 \mathrm{~g}$ were used. Mice were kept at controlled temperature $\left(22 \pm 2^{\circ} \mathrm{C}\right)$, humidity $(50 \%)$ and $12 \mathrm{~h}$ light/dark cycles, in a number of three to five per cage and commercial rodent diet and water were available ad libitum.

Mice infection with Leishmania mexicana. Mice were infected at one month of age at left footpad with $10 \mu \mathrm{L}$ of a parasite suspension containing 108 promastigotes $/ \mathrm{mL}$ of MNYC/BZ/62/M379 Leishmania mexicana strain2. The lesion started four weeks after infection.

Register of footpad lesion size was performed once a week by using a Vernier. Mice were sacrificed four weeks after treatment ends.

\section{Molecular modelling}

Some compounds were picked to analyse the lowest energy conformation to establish a correlation between structure and biological activity. The lowest energy conformation was found by using the keyword modredundant in the package gaussian $09^{13}$ by combination for the two more rotatable bonds. Once we get the general lowest energy conformation, two more advanced methods were used to analyse the conformation for the methoxy group attached to the aromatic rings. As we suspected the presence of a non-classical interaction between fluorine and hydrogens from the aromatic ring, we make a conformational search in the methoxy moiety with 80 points scans using the theory level functional B3LYP**, which can differentiate easily between coplanar and orthogonal conformations.

In parallel, we conducted a molecular dynamics simulation for protein-ligand complexes. Leishmania major proteins were used as models of Leishmania sp. proteins. Homology protein for ImDHFR was constructed utilising the web-server https://swissmodel.expasy.org. For ImPTR1 and hDHFR, proteins were taken from the protein databank (1WOC and 1KMS codes respectively). The initial input was taken from previous docking studies already published. Complexes protein-ligand and NADP were generated by using the tleap module implemented in Ambertools 18. ${ }^{14}$ Complexes were subjected to a protocol of minimisation and equilibration with Sander implemented in Ambertools18 as well. MD production was performed with SOMD as implemented in the Sire package for 560 ns. ${ }^{15}$ analysis was performed with Gromacs (using gmx angle). ${ }^{16}$

POVME3.0 software was used overall trajectories to measure binding pocket volumes. ${ }^{17}$
All plots were generated with Originlab software and figures with VMD and Pymol. ${ }^{18}$

\section{Acknowledgements}

Our gratitude is expressed to Dr. Julien Michel for his support in the computational studies. This study was sponsored by grants from UNAM-DGAPA-PAPIIT IN223120, CONACYT-SEPCB220664. We are grateful to Rosa Isela del Villar, Nayeli López Georgina Duarte, and Marisela Gutiérrez from Facultad de Química-USAI, UNAM, for the determination of all spectra.

Keywords: Leishmania mexicana, quinazoline, Fluorine, Antileishmanial agents, Computational Drug design.

[1] E. K Davison, M. A Brimble, Current Opinion in Chemical Biology 2019. 52 $1-8$

[2]. O. O. Ajani, O. Y. Audu, D. V. Aderohunmu, F. E. Owolabi, A. O. Olomieja. American Journal of Drug Discovery and Development 2017, 7: 1-24.

[3] J. G.B. Pedreira, L. S. Franco, E. J. Barreiro. Current Topics in Medicinal Chemistry 2019, 15: 1679-1693.

[4]. Y. Li, Q. Meng, M. Yang, D. Liu, X. Hou, L. Tang, X. Wang, Y. Lyu, X. Chen, K. Liu, A. Yu, Z. Zuo, H. Bi. Acta Pharmaceutica Sinica B 2019. 9: 1113-1144.

[5] https://www.who.int/leishmaniasis/en/

[6] M. T. Armúa-Fernández, J. M. Venzal. Veterinaria (Montevideo), 2019. 55: 29-36. https://dx.doi.org/10.29155/vet.55.211.5

[7] C. Mendoza-Martínez, N. Galindo-Sevilla, J. Correa-Basurto, V. M. UgaldeSaldivar, R. G. Rodríguez-Delgado, J. Hernández-Pineda, C. Padierna-Mota, M. Flores-Alamo, F. Hernández-Luis. European Journal of Medicinal Chemistry 2015. 92: 314-331.

[8] C. Mendoza-Martínez, J. Correa-Basurto, R. Nieto-Meneses, A. MárquezNavarro, R. Aguilar-Suárez, M. Dinora Montero-Cortes, B. Nogueda-Torres, E. Suárez-Contreras, N. Galindo-Sevilla, Á. Rojas-Rojas, A. Rodriguez-Lezama, F. Hernández-Luis. European Journal of Medicinal Chemistry 2015. 96: 296-307. [9] E. Li, Q. Lin, Y. Meng, L. Zhang, P. Song, N. Li, J. Xin, P. Yang, C. Bao, D. Zhang, Y. Zhang, J. Wang, Q. Zhang, H. Liu. European Journal of Medicinal Chemistry 2019. 172: 36-47.

[10] L. Huijuan, Q. Yuan, Z. Denghui, Z. Qiang, G. Ju, T. Yuanhao, Y. Jiahuan, L. Kun, Y. Lan, C. Shuang, Z. Weilong, M. Jing, L. Yanrong, S. Tao, Y. Cheng Molecular Cancer Therapeutics. 541- 555. DOI : 10.1158/1535-7163.

[11] L. Xing, D. C. Blakemore, A. Narayanan, R. Unwalla, F. Lovering, R. Aldrin Denny, H. Zhou, M. E. Bunnage. ChemMedChem 2015. 10: 715 - 726.

[12] B. Orzeszko, M. Fedoryński, AE Laudy, BJ Starościak, A. Orzeszko, Synthesis and antibacterial activity of 5-adamantan-1-yl-methyl analogues of trimethoprim. Acta Poloniae Pharmaceutica. 2006. 63(5): 374-377.

[13] Gaussian 09, Revision A.02, M. J. Frisch, G. W. Trucks, H. B. Schlegel, G. E. Scuseria, M. A. Robb, J. R. Cheeseman, G. Scalmani, V. Barone, G. A Petersson, H. Nakatsuji, X. Li, M. Caricato, A. Marenich, J. Bloino, B. G. Janesko, R. Gomperts, B. Mennucci, H. P. Hratchian, J. V. Ortiz, A. F. Izmaylov, J. L. Sonnenberg, D. Williams-Young, F. Ding, F. Lipparini, F. Egidi, J. Goings, B. Peng, A. Petrone, T. Henderson, D. Ranasinghe, V. G. Zakrzewski, J. Gao, N. Rega, G. Zheng, W. Liang, M. Hada, M. Ehara, K. Toyota, R. Fukuda, J. Hasegawa, M. Ishida, T. Nakajima, Y. Honda, O. Kitao, H. Nakai, T. Vreven, K. Throssell, J. A. Montgomery, Jr., J. E. Peralta, F. Ogliaro, M. Bearpark, J. J. Heyd, E. Brothers, K. N. Kudin, V. N. Staroverov, T. Keith, R. Kobayashi, J. Normand, K. Raghavachari, A. Rendell, J. C. Burant, S. S. Iyengar, J. Tomasi, 
M. Cossi, J. M. Millam, M. Klene, C. Adamo, R. Cammi, J. W. Ochterski, R. L. Martin, K. Morokuma, O. Farkas, J. B. Foresman, and D. J. Fox, Gaussian, Inc., Wallingford CT, 2016.

[14] D.A. Case, K. Belfon, I.Y. Ben-Shalom, S.R. Brozell, D.S. Cerutti, T.E. Cheatham, III, V.W.D. Cruzeiro, T.A. Darden, R.E. Duke, G. Giambasu, M.K. Gilson, H. Gohlke, A.W. Goetz, R. Harris, S. Izadi, S.A. Izmailov, K. Kasavajhala A. Kovalenko, R. Krasny, T. Kurtzman, T.S. Lee, S. LeGrand, P. Li, C. Lin, J. Liu, T. Luchko, R. Luo, V. Man, K.M. Merz, Y. Miao, O. Mikhailovskii, G. Monard, H. Nguyen, A. Onufriev, F.Pan, S. Pantano, R. Qi, D.R. Roe, A. Roitberg, C. Sagui, S. Schott-Verdugo, J. Shen, C.L. Simmerling, N.R.Skrynnikov, J. Smith, J. Swails, R.C. Walker, J. Wang, L. Wilson, R.M. Wolf, X. Wu, Y. Xiong, Y. Xue, D.M. York and P.A. Kollman (2020), AMBER 2020, University of California, San Francisco.

[15] G. Calabrò, C. J. Woods, F. Powlesland, A. S. J. S. Mey, A. J. Mulholland, and J. Michel. The Journal of Physical Chemistry B. 2016120 (24): 5340-5350. [16] Berendsen, D. van der Spoel, R.van Drunen. GROMACS: A messagepassing parallel molecular dynamics implementation. Computer Physics Communications, 1995. 91(1-3): 43-56.

[17] J. R. Wagner, J. Sørensen, N. Hensley, C. Wong, C. Zhu, T. Perison, and R. E. Amaro. Journal of Chemical Theory and Computation. 201713 (9): 45844592

[18] Humphrey, W., Dalke, A. and Schulten, K., VMD - Visual Molecular Dynamics. Journal Molecular Graphics. 1996. 14:33-38. 


\section{Entry for the Table of Contents}

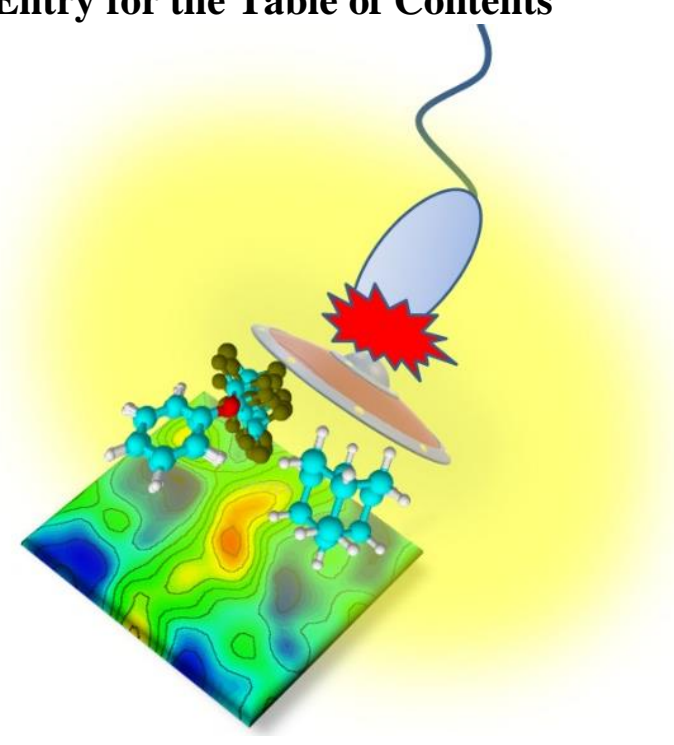

There is an urgency of finding molecules available to treat Leishmaniosis, which is one of the significant issues of health in undeveloped countries. For that reason is needed to explore molecular diversity to find novel scaffolds. Fluorinated and adamantane derivatives exhibit a formidable starting point. They are proved to improve the antileishmanial activity when attached to molecules already active as we have shown in this paper. Particularly fluorinated methoxy and ethoxy derivatives can increase its volume depending on the number of fluorine, a unique behaviour that can be exploited for molecular drug design purposes. 